\title{
Knowledge Spillover Effects of International Trade of OECD Countries
}

\author{
Ding Weina \\ School of Management and Economics \\ Beijing Institute of Technology \\ Beijing, PR. China \\ dingdingdd@bit.edu.cn \\ Han Botang \\ School of Management and Economics \\ Beijing Institute of Technology \\ Beijing, PR. China \\ hbt5@bit.edu.cn
}

\author{
Zhao Xin \\ School of Management and Economics \\ Beijing Institute of Technology \\ Beijing, PR. China \\ 3120130603@bit.edu.cn
}

\author{
Zhang Ni \\ School of Management and Economics \\ Beijing Institute of Technology \\ Beijing, PR. China \\ ashymilk@163.com
}

\begin{abstract}
The international trades have make a significant impact on economic growth to the world's major economies organizations. If China wants to achieve sustainable economic growth rapidly with low cost, it should obtain advanced knowledge and technology from the international trade with developed countries of technology and knowledge overflow. How to cooperate with these developed countries and what kind of trade we should do to gain the most spillovers effect is the issues discussed in this paper, which use the panel data from 1995 to 2010 , do the empirical test to the $R \& D$ spillover effects on some of OECD countries which have more international trade with China, and thus lay the foundation for further study of the relationship between spillovers and regional innovation capacity.
\end{abstract}

Keywords-International Trade; Knowledge Spillover; Foreign R\&D; CH Method; OECD Countries;

\section{INTRODUCTION}

International trade brings new products to countries involved. At the same time, new products provide the opportunity to the importer country to imitate the production, which means the process of learning new techniques can generate the technology spillovers and make the importer to enhance the level of technical innovation. In addition, imported goods will affect the market share of local products, thereby it indirectly stimulate local to break through by technological innovation activities. In particular, with various forms of technical guidance of imports, technological innovations will spread to the importer in different degree. In the meanwhile, international trade influences the economic structures and social developments to both sides of the trading nations in directly. It affects a country's economic growth by changing some basic elements of economic growth, increasing the capital accumulation, improving industrial structure, and promoting technological progress.

In the 1980s Grossman and Helpman (1991) had studied the relationship between trade, innovation and growth by using the endogenous growth model. The empirical research on the effect of the international trade on technology spillover and total factor productivity (TFP) was carried out by Coe and Helpman (1995) for the first time. The latest progress of the international trade theory in the $21 \mathrm{st}$ century, is that the trade model with heterogeneous firms(HFTM) and endogenous boundary model of the firm were widely used. The analysis has paid more attention on micro operations of enterprises than the macro, meso-operations of international trade, which is known as the "new new trade theory". Tyler (1981) used linear regression mode to study the role of exports, labor and capital to total output, and found that export is an important factor affecting economic growth.

\section{PROBLEM STATEMENT}

On the measure of international technology spillovers, many studies applied regression methods, which took technology spillover channels or mechanisms into analysis, to observe whether the activities of foreign economic and technological changes can affect domestic technology. Coe and Helpman (1995) took bilateral import shares as weights to construct the stock of foreign $R \& D$ and analyzed how the R\&D of exporter affects the importer's technological advancement through international technology spillover(short for $\mathrm{CH}$ method). $\mathrm{CH}$ method using the import share to weight the importers' R\&D) became a universal practice of studying the international technology spillover through the international trade Lichtenberg and Pottelsbergue (1996) believed that there are some errors in the $\mathrm{CH}$ model when it measures the stock of foreign $\mathrm{R} \& \mathrm{D}$, and their modification is using the ratio of imports to GDP as weights to measure foreign R\&D stock (short for LP method) .

Previous studies have shown that, in general, there is a positive relationship between the $R \& D$ investment of exporters and the importer's TFP, which is, the international technology spillovers play a positive role in promoting the importer's TFP, when international trade is considered as the transmission mechanism. This also works for China. International trade indirectly promotes 
China's technological progress and technological innovation.

\section{THEORETICAL MODEL}

This section will build econometric model to study knowledge spillovers of foreign R\&D through China's import trade. Coe and Helpman (1995) established the $\mathrm{CH}$ model by assuming that $\mathrm{S}$ depends on domestic intellectual capital $\left(S^{d}\right)$ and foreign knowledge spillovers $\left(S^{f}\right)$. Presentation is as follows:

$$
\ln F_{\text {it }}=\alpha_{0}+\alpha_{1 t} \ln S_{i t}{ }^{d}+\alpha_{2 t} \ln S_{i t}{ }^{f(\mathrm{CH})}+\varepsilon_{i t}
$$

Let $F_{i t}$ be the TFP of country $\mathrm{i}$ at time $\mathrm{t} ; S_{i t}{ }^{d}$ is the domestic R\&D capital stock of country $i$ at time $t$; $S_{i t}{ }^{f(\mathrm{CH})}$ represents the domestic R\&D capital stock of country $\mathrm{i}$ at time $\mathrm{t}$ calculated by $\mathrm{CH}$ method; $\alpha_{0}$ is a constant; $\alpha_{1}$ refers the resilience of the i-th country's domestic R\&D capital stock to domestic TFP; $\alpha_{2}$ indicates the resilience of foreign R\&D spillovers to domestic TFP; $\varepsilon_{i t}$ is random disturbance.

Lichtenberg and Pottelsbergue (1996) improved the $\mathrm{CH}$ method (referred to as LP method), they gave a new measurement method as follows:

$$
S_{i t}{ }^{f(\mathrm{LP})}=\sum_{j \neq i} \frac{I M_{i j f}}{G D P_{j t}} \times S_{j t}{ }^{\mathrm{d}}
$$

$S_{i t}{ }^{f(\mathrm{LP})}$ represents the domestic R\&D capital stock of country $\mathrm{i}$ at time t calculated to the LP method; $G D P_{j t}$ is the GDP of $\mathrm{j}$ - country at time $\mathrm{t}$.

Based on the $\mathrm{CH}$ spillovers econometric model, this paper establishes the model of foreign R\&D spillover from the aspect of China's imports and modifies that part by adopting LP method, then adds the time trend parameters for investigating the impact of the time factor. Presentation of the international trade spillover model is as follows:

$$
\begin{aligned}
\ln F_{\mathrm{it}}= & \alpha_{i 0}+\alpha_{i 1} \mathrm{t}+\alpha_{t 2} \ln S_{i t}{ }^{d} \\
& +\alpha_{i 3} \ln S_{i t}{ }^{\mathrm{im}(\mathrm{LP})}+\varepsilon_{i t}
\end{aligned}
$$

$F_{i t}$ represents the domestic TFP of i-th developing country at time $\mathrm{t} ; S_{i t}^{d}$ denotes the domestic R\&D of i-th country in period t. $S_{i t}{ }^{\mathrm{im}(\mathrm{LP})}$ represents the domestic R\&D capital stock of country $\mathrm{i}$ at time $\mathrm{t} ; \alpha_{0}$ is a constant; $\alpha_{1}$ represents the impact of time factor on domestic TFP; $\alpha_{2}$ represents the resilience of the i-th country's domestic R\&D capital stock to domestic TFP; $\alpha_{3}$ represents the resilience of foreign R\&D overflow to domestic TFP. $\varepsilon_{i t}$ is random disturbance.

\section{EMPIRICAL ANALYSIS}

The econometric model established above has been applied to do empirical analysis on part of the OECD countries with time-series data from 1995 to 2010, including Australia, the USA, Japan, Korea and other typical economies.

\section{A. Descriptions of model variables and calculations}

Variables involved contain the TFP of each country, the domestic R\&D stock and the foreign R\&D stock overflowed by import. The calculations and estimations of each variable will be given in the following.

1) TFP:

Let $F_{\mathrm{t}}$ denotes the domestic TFP of every developing country at time $\mathrm{t}$.

$$
F_{t}=Y_{t} / K_{t}^{\alpha} L_{t}^{\beta}
$$

$\alpha$ and $\beta$ respectively denote the output elasticity of capital and labor.

Calculating the logarithm of the Eq.(4), we get a double logarithmic model:

$$
\ln Y_{\mathrm{t}}=\ln A+\alpha \ln K_{\mathrm{t}}+\beta \ln L_{\mathrm{t}}+\varepsilon_{\mathrm{t}}
$$

Then we can use ordinary least squares method to estimate the parameters. Prior to that, the capital stock is needed, which uses perpetual inventory method invented by HuIten and Wykoff in 1981 to do the calculation. Calculation equation is as following:

$$
K_{\mathrm{t}}=I_{\mathrm{t}} / P_{t}+(1-\delta) \mathrm{K}_{t-1}
$$

$K_{\mathrm{t}}$ is the actual capital stock in year $\mathrm{t} ; P_{t}$ is the price index of investment in fixed assets; $I_{\mathrm{t}}$ denotes the nominal investment; Depreciation rate is assumed to be $5 \%$; due to lack of investment price index, we use the consumer price index of each region to instead and take 1985 as the base year. The estimation of R\&D stock is based on the estimation of capital stock in 1985, and carried out with $\mathrm{CH}$ (1995) method as follows:

$$
K_{1985}=I_{1985} /(\mathrm{g}+\delta)
$$

$\mathrm{g}$ is the average of fixed capital expenditure logarithmic growth of every region in $1985-2010, \delta$ is the capital depreciation rate, which is this is set to be $5 \%$ as Maurice Schiff, Yanling Wang and Marcelo Olarreaga (2002) settled in their approach.

$Y_{\mathrm{t}}$ denote the total annual output; $K_{\mathrm{t}}$ and $L_{\mathrm{t}}$ are capital and labor input respectively in year t; We take GDP as the total annual output, which is calculated according to the expenditure approach, and the prices of GDP are converted into 1985. The number of persons employed in all regions is chosen to represent the labor input. Using ordinary least squares regression to analyze the time series data, we get $\alpha=0.42, \beta=0.58$.

2) The stock of domestic $R \& D$ :

According to the Coe\&Helpman's approach (1995), the calculations of the stock of domestic $R \& D$ are as following:

$$
S_{t}=R_{t-1}+(1-\delta) \times S_{t-1}
$$

$S_{t}$ denotes the R\&D capital stock in the year t; $R_{t-1}$ denotes the $\mathrm{R} \& \mathrm{D}$ expense in the year $\mathrm{t}-1 ; \delta$ denote depreciation rates; In addition, assumptions of domestic R\&D stock depreciation rates were $5 \%$ and $10 \%$,and it was $10 \%$ for the foreign $R \& D$.

$$
S_{0}=R_{0} /(\mathrm{g}+\delta)
$$


$S_{0}$ denotes China's capital stock in the base year; $R_{0}$ denotes the $\mathrm{R} \& \mathrm{D}$ expenditure in the base year; $\mathrm{g}$ denote growth rates of the average of annual $R \& D$ expenses; $\delta$ denote depreciation rates; We select 1970 as the base year because of its more complete data. After calculation of domestic R\&D stock in 1970 according to Eq. (9), we can calculate all the domestic R\&D stocks in the following years by Eq. (8).

3) The amount of $R \& D$ spillover of foreign imports:

$S_{i t}^{i m(\mathrm{LP})}$ In this section we calculate the amount of R\&D spillover of foreign imports with LP (1996) method.

$$
S_{t}^{f(\mathrm{LP})}=\sum_{j \neq i} \frac{I M_{j t}}{G D P_{j}} \times S_{j}^{\mathrm{d}}
$$

$\mathrm{j}$ is the number of the selected OECD countries, such as USA, Japan, Germany, France, the Netherlands. These countries not only have larger national and international trade but relatively have high stocks of domestic R\&D in developed countries.

$G D P_{j}$, the GDP of country $\mathrm{j}$, and $S_{j}{ }^{\mathrm{d}}$ represents the domestic R\&D stock; $I M_{j t}$ is the amount of export from country j to China.

\section{B. Empirical Results Analysis}

In order to investigate China's R\&D spillovers flowed from the 26 OECD countries through imports, this section will apply regression analysis to the time series data from 1995-2010.

\section{1) Unit Root Test}

To avoid drastic changes in the data, firstly the logarithms of $F_{\text {it }}, S_{t}, S_{i t}^{\text {im(LP) }}$ should be calculated. Secondly, do ADF unit root test. As shown in Table 1, all the data get through the stationary test at $10 \%$ level significantly. That is to say the time series data is stationary, so we can use the regression approach in further analysis.

TABLE I. The RESUlt of Unit Root Test

\begin{tabular}{lccc}
\hline & & T value & P value \\
\hline $\ln F_{\text {it }}$ ADF statistic & & -4.398152 & $0.0024^{*}$ \\
\hline The critical value & $10 \%$ level & -3.133051 & \\
\hline $\ln S_{t}$ ADF statistic & & -2.833278 & $0.0545^{*}$ \\
\hline The critical value & $10 \%$ level & -2.570428 & \\
\hline $\ln S_{i t}{ }_{\text {im(LP) }}$ ADF statistic & & -4.684223 & $0.0008^{*}$ \\
\hline The critical value & $10 \%$ level & -3.133051 & \\
\hline
\end{tabular}

*MacKinnon (1996) one-sided p-values.

\section{2) Empirical results}

After the stationary test, we provide regression

analysis to the time series data that China trade with 26 OECD countries. It aims to research the R\&D spillovers arising from the export which is from developed countries to China.
TABLE II. THE REGRESSION RESULTS OF THE TIME SERIES DATA

\begin{tabular}{|c|c|c|c|c|c|c|}
\hline Series & Cons & T-Stat & Prob. & $D W$ & $R$ & $\begin{array}{l}\text { Adj } . \\
R\end{array}$ \\
\hline $\mathrm{C}$ & -1.8697 & -36.224 & 0.000 & & & \\
\hline $\ln S_{t}$ & 0.3039 & $42.497 *$ & 0.000 & 0.53 & 0.97 & 0.96 \\
\hline $\ln S_{i t}^{\mathrm{im}(\mathrm{LP})}$ & 0.0338 & 4.013 & 0.000 & & & \\
\hline Australia & 0.0000 & 2.555 & 0.006 & & & \\
\hline Austria & 0.0000 & 1.849 & 0.066 & & & \\
\hline $\begin{array}{l}\text { Czech } \\
\text { Republic }\end{array}$ & 0.0006 & 2.727 & 0.007 & & & \\
\hline Denmark & 0.0001 & 2.229 & 0.027 & & & \\
\hline Finland & 0.0000 & 1.640 & 0.102 & & & \\
\hline France & 0.0000 & 2.710 & 0.007 & & & \\
\hline Germany & 0.0000 & 1.743 & 0.083 & & & \\
\hline Ireland & 0.0000 & 0.764 & 0.445 & & & \\
\hline Israel & 0.0000 & 1.031 & 0.304 & & & \\
\hline Italy & 0.0000 & 3.601 & 0.000 & & & \\
\hline $\begin{array}{l}\text { Luxem- } \\
\text { bourg }\end{array}$ & 0.0002 & 2.611 & 0.010 & & & \\
\hline $\begin{array}{l}\text { Nether- } \\
\text { lands }\end{array}$ & 0.0000 & 3.837 & 0.000 & & & \\
\hline Norway & 0.0001 & 2.298 & 0.022 & & & \\
\hline Poland & 0.0000 & 0.519 & 0.604 & & & \\
\hline Spain & 0.0000 & 4.411 & 0 & & & \\
\hline Sweden & 0.0000 & 1.951 & 0.052 & & & \\
\hline $\begin{array}{l}\text { United } \\
\text { States }\end{array}$ & 0.0000 & 3.450 & 0.001 & & & \\
\hline
\end{tabular}

Note: *denotes that the level of $\mathrm{T}$ test is smaller than the significance level 5\%; Because the intercept item has not pass $\mathrm{T}$ test, we delete the intercept item; The regression is referred to the fixed effect model.

The regression results show that the technology spillovers arise from the international trade between China and 26 OECD countries. Besides Finland, Ireland, Israel and Poland, the other countries' elasticity of foreign R\&D stock to TFP are significantly positive. In addition, the trade spillover effects of Italy, Netherlands, Spain and the United States are more obvious, and China's imports from these countries are up to $\$ 140$ billion, $\$ 65$ billion, $\$ 17$ billion, $\$ 62$ billion, $\$ 1021$ billion, respectively in 2010 .

The bilateral trade of China between US has a significant impact on China's economic development. The bilateral trade is founded on the gap of technical strength, and this kind of trade is bad for the weaker one. However, with the rise of China's technological strength and knowledge stocks, the technology gap with the United States is narrowed, and the trade relation between the two countries gradually dominated by competition other than complementary.

The R\&D spillovers obtained from trade affect China's TFP significantly. China's imports from Italy, Spain and other EU countries are involved in the technical equipment, aircraft, ships, machinery products, electronic communications equipment, pharmaceuticals, chemicals and steel. The impact of these imports on the stock of knowledge and technology spillovers in China is very significant and important. For example, China's trade with Australia has been very close. China has become Australia's largest trading partner since 2009, largest export destination and largest source of imports. Although China-Australia economic and trade relations are highly 
complementary, the main imports from Australia are over natural resources, minerals, energy products and agricultural products, and the impact of these commodities to China's R\&D spillovers is not very significant.

\section{CONCLUSIONS}

For developing countries which have lower technical level, the impacts of technological spillovers obtained from international trade in promoting their technological progress and economic growth are more specific and important. China can take advantage of technology spillovers arising from international trade to accelerate technological progress, thus contributing to economic growth and take off.

This paper has quantified technology spillovers of 17 OECD countries arising from China's international trade, and has applied empirical tests to China's TFP, domestic R\&D stock and the stock of foreign trade spillover. The results show that, in general, technology spillovers arise from international trade would play a positive role in promoting China's technological progress. However it is different in different countries, in some countries the international trade does not produce technology overflows significantly. One important reason is the difference between imports of goods from various countries. For example, China's imports of technology equipment and electronic communication products are mainly from the United States and the European Union. These high-tech products are mostly gained more R\&D spillovers obviously. However, resource commodities from Australia and other countries account for the major part of imports, and therefore it produces less significant effect in R\&D spillovers.

The technology spillovers are also affected by national technical monopoly, the level of economic development and location of the country which introduces technologies, and many other factors such as restriction of trade structure. The overflows of technology are nonspontaneous, that multiply difficulties to the technology spillovers. Moreover, developing countries need to digest and absorb the imported technologies, and accelerate the innovate ability on the basis of imitation learning to make the country achieve the expected in the use of international technology spillovers. Therefore, China should strive to improve their skill level and knowledge of the stock, and increase the imports of high-tech and other high-tech goods. In a sum, we can accelerate and promote the level of China's independent innovation capability by more significant spillovers achievement.

\section{ACKNOWLEDGMENT}

This work is partially supported by National Science \& Technology Program, "The Knowledge Spillover Effect on China's regional economic growth in the economic crisis", NO. 70973011.

\section{REFERENCES}

[1] Coe, David T., Elhanan Helpman, "International R\&D Spillovers, ” European Economic Review,Vol.39, May1995,pp.859_887.

[2] Grossman Gene M. and Elhanan Helpman, Innovation and Growth in the Global Economy, Cambridge, Massachusetts: MIT Press, 1991.

[3] Lichtenberg F., B Van Pottelsberghe de 1a Potterie, "International R\&D Spillovers: A re-examination," NBER Working Paper, No.5688, Jul.1996.

[4] Tyler, "Growth and export expansion in developing countries: some empirical evidence," Journal of Development Economics, Vol 9, Aug.1981, pp.121-30.

[5] Olivier Lumenga-Neso, Marcelo Olarreaga, Maurice Schiff, "On 'indirect' trade-related R\&D spillovers," European Economic Review, Vol. 49, Oct.2005, pp.1785-1798. 